\title{
A community-based education program about cervical cancer improves knowledge and screening behavior in Honduran women
}

\author{
Rebecca B. Perkins, ${ }^{1}$ Sarah Langrish, ${ }^{2}$ Linda Jo Stern, ${ }^{2}$ Carol J. Simon ${ }^{3}$
}

Suggested citation

Perkins RB, Langrish S, Stern LJ, Simon CJ. A community-based education program about cervical cancer improves knowledge and screening behavior in Honduran women. Rev Panam Salud Publica. 2007:22(3):187-93.

ABSTRACT Objectives. This study examined changes in knowledge and behavior after a communitybased cervical cancer education program in Honduras.

Methods. The program consisted of radio broadcasts targeting rural women and presentations to community nurses. The effectiveness of the radio broadcasts was assessed using a cross-sectional design (control groups $n=124, n=243$; intervention group $n=233$ ). A pre-/ post-test design was used to evaluate the nurses' training program $(n=32)$. A subset of nurses $(n=16)$ was retested two years later. Evaluation included $t$ tests, chi-square and Fisher exact analyses.

Results. The radio broadcast increased the proportion of women who were familiar with the term "cervical cancer," who could identify means of preventing cervical cancer, and who understood the purpose of the Pap smear. In addition, older and under-screened women were successfully recruited for screening via radio. The nurses' program improved understanding of the correct use of the Pap smear, the age-related risk of dysplasia, and the proper triage of abnormal results. The nurses retained a significant amount of knowledge two years after this training. Conclusions. In developing countries, inexpensive, community-based educational programs using radio broadcasts and lecture presentations can increase cervical cancer knowledge and improve screening behavior.

Key words Communications media; developing countries; female; health education; mass screening; uterine cervical neoplasms/dysplasia; Honduras.

Cervical cancer is the leading cause of cancer death among women in de-

\footnotetext{
Department of Obstetrics and Gynecology, Boston University, Boston, Massachusetts, U.S.A. Send correspondence to: Rebecca B. Perkins, Dept. of Obstetrics and Gynecology, Boston University, 85 E. Concord St., Boston, Massachusetts 02118, U.S.A.; telephone: 617-710-7446; fax: 617-277-2370; e-mail: rebecca.perkins@bmc.org.

2 Emma Romero de Callejas Centro de Cancer, Tegucigalpa, Honduras.

3 Department of Health Services, Boston University School of Public Health, Boston, Massachusetts, U.S.A.
}

veloping countries, primarily due to the lack of organized screening programs (1). To obtain a Pap smear, each woman must proactively seek screening opportunities. Because the onus of screening is on the individual, each woman's understanding of cervical cancer prevention becomes crucial in her decision to obtain a Pap smear. As expected, prior research shows a positive association between a woman's knowledge about cervical cancer screening and her likelihood of obtaining a Pap smear (2-5). The recommendation of a health care provider can also influence screening behavior (6-8), but many providers in developing countries lack basic knowledge about cervical cancer prevention (9-12).

In Honduras, the incidence of cervical cancer is 39.6/100 000, four times that of the United States $(13,14)$; it is the leading cause of cancer death for women. Honduras does not have an 
organized screening program, which likely contributes to the high mortality from cervical cancer. We created an educational program to generate interest in cervical cancer prevention and to create a culture of screening among patients and providers that would persist after the education program ended. To make the most sustainable program possible, local health providers and other community members worked alongside project staff to create a twopart educational program that addressed the knowledge deficits of the community. The objectives of this pilot project were to improve knowledge about cervical cancer prevention and to promote acceptance of Pap smear screening among Honduran women and their health care providers.

\section{MATERIALS AND METHODS}

\section{Setting}

The project took place in the communities of Yuscaran, Moroceli, and Jicarito in Honduras. The total population of these communities is approximately 30,000, of whom 8,000 are women of reproductive age. Twothirds of the population lives below the poverty line and half lacks basic sanitation and potable water. The average person has had 2-3 years of schooling, and $30 \%$ of the population is illiterate (15). There are two regional radio stations, and most families have battery-powered radios.

\section{Timeline}

The project timeline is detailed in Figure 1. The first step, which occurred between July and September 2003, was a baseline assessment of cervical cancer knowledge and screening behavior in the region. During October 2003, members of a U.S.-based nongovernmental organization worked together with Honduran community leaders to develop educational programs appropriate to women in the community and their health care providers. The educational program

FIGURE 1. Timeline of cervical cancer education projects and evaluations in Honduras; 2003 to 2005

\begin{tabular}{|c|c|c|c|c|}
\hline 7/03-8/03 & $9 / 03$ & $10 / 03$ & $11 / 03$ & $11 / 05$ \\
\hline $\begin{array}{l}\text { Assessment: } \\
\text { Community } \\
\text { knowledge } \\
\text { prior to radio } \\
\text { broadcasts }\end{array}$ & $\begin{array}{l}1 \\
\text { Assessment: } \\
\text { Screening } \\
\text { behavior } \\
\text { prior to radio } \\
\text { broadcasts }\end{array}$ & $\begin{array}{c}\downarrow \\
\text { Radio } \\
\text { Broadcasts }\end{array}$ & $\begin{array}{l}\text { Evarses' Training } \\
\text { Evaluation: } \\
\text { Knowledge and } \\
\text { behavior following } \\
\text { radio broadcasts }\end{array}$ & $\begin{array}{c} \\
\text { Evaluation: } \\
\text { Nurses' } \\
\text { knowledge } \\
\text { at two years }\end{array}$ \\
\hline
\end{tabular}

for the general public provided information using radio broadcasts. The program for training health care providers consisted of a lecture presentation at the nurses' monthly educational session.

The following messages were emphasized in both educational programs: (a) the Pap smear is the key to preventing cervical cancer, and (b) women aged 30 and over are most at risk for pre-cancerous changes.

\section{Radio program}

The radio program consisted of a series of broadcasts on one of the two radio stations in the region. The primary broadcast was an hour-long, stressed the importance of cervical cancer screening, and stated that women aged 30 and over and those who had not been screened in two or more years were at higher risk for developing dysplasia. Short messages emphasizing salient points were also aired. Both U.S. and Honduran health care providers participated in program writing and performance. The hour-long program was broadcast twice daily and the short messages were broadcast at 15 to 30 minute intervals for one week prior to an organized screening activity. No other cervical cancer education programs existed in the region at this time.
Knowledge about cervical cancer was assessed in a sample of women in the community (Group 1: Community knowledge prior to radio broadcasts; $\mathrm{n}=124)$. These data were used to represent knowledge in the community at baseline. The women selected for these interviews included all women that were participating in a housing improvement project being conducted by our organization. ${ }^{4}$ All interviews were completed before the radio broadcasts began to ensure that no one in the control group could be influenced by the educational programming.

Unfortunately, screening behavior could not be adequately assessed in the women who participated in the community knowledge assessment (Group 1). Therefore, a second group of women was used to represent screening behavior. All women who presented for Pap smears at two orga-

\footnotetext{
4 All women participated in interviews, but only those women who had a prior history of Pap screening were included in the final analysis. This decision was made because women who have never been screened know less about cervical cancer $(3,4)$ and there were more unscreened women in the community sample than in the sample used to assess knowledge and behavior after the radio program. To avoid biasing the results toward a positive finding by the unequal distribution of unscreened women, the analysis in all groups was limited to only those women reporting a prior history of screening. A majority of women in both samples reported at least one prior Pap smear; the number of unscreened women in each group was too small to allow for meaningful statistical analysis.
} 
nized screening activities that occurred prior to the radio broadcasts were included in Group 2 (Screening behavior prior to radio broadcasts; $\mathrm{n}=243$ ).

Group 1 (Community knowledge prior to radio broadcasts; $\mathrm{n}=124$ ) and Group 2 (Screening behavior prior to radio broadcasts; $\mathrm{n}=243$ ) were compared to a group that included all women attending an organized screening activity that occurred immediately after the radio broadcasts (Group 3: Knowledge and behavior following radio broadcasts; $\mathrm{n}=233$ ). ${ }^{5}$ Women in Groups 1, 2, and 3 lived in separate villages located within the same region of Honduras; the socioeconomic status and access to health care were similar for all three groups.

Structured interviews were used to assess knowledge levels in the community before and after the radio broadcasts. The percentage of correct responses in Group 1 (Community knowledge prior to radio broadcasts; $\mathrm{n}=124$ ) was compared to the percentage of correct responses in Group 3 (Knowledge and behavior following radio broadcasts; $n=233$ ). The success of the radio program in recruiting high-risk women for screening was assessed by comparing the number of high-risk women presenting for screening before the radio broadcasts (Group 2; n = 243) and after the broadcasts (Group 3; $\mathrm{n}=233$ ). High-risk women were defined in the radio broadcast as those aged 30 and over and those whose most recent Pap smear was two or more years earlier.

\section{Training for community nurses}

The training for community nurses consisted of a 45-minute lecture with visual aids given during the nurses' monthly educational meeting. The lecture focused on the importance of screening, the age group at highest risk for dysplasia, and the Pap smear results that required referral to a gynecologist.

\footnotetext{
5 To make Groups 1, 2, and 3 as comparable as possible, only women with a prior history of Pap screening were included in the final analysis.
}

Approximately $70 \%$ of the nurses staffing the health centers involved in the project attended the lecture program. The same nurses participated in the pre-intervention, post-intervention, and two-year post-intervention evaluations.

The effectiveness of the presentation was assessed by comparing the percentage of correct answers on pre- and post-intervention questionnaires. A combination of free response and forced-choice questions were included. Two years after the initial intervention, those nurses who had heard the original presentation and were still working in the communities were surveyed to determine their level of knowledge retention.

\section{Data analysis}

The use of the data for research purposes was approved by the Institutional Review Board of Boston University. Data were analyzed using SAS statistical software Version 8.2 (SAS Institute Inc., Cary, North Carolina, U.S.A.). Demographic characteristics, knowledge, and screening behaviors were compared for (Group 1: Community knowledge prior to radio broadcasts; $n=124)$, (Group 2: Screening behavior prior to radio broadcasts; $\mathrm{n}=$ 243), and Group 3 (Knowledge and behavior following radio broadcasts; $\mathrm{n}=$ 233). We then assessed the impact of the radio program on knowledge and recruitment of high-risk women for screening. Student $t$ tests and chisquare analyses were used. Fisher exact tests were used to assess the impact of the nurses' training program.

\section{RESULTS}

\section{Radio program}

Comparison of demographic characteristics. Because this study was not randomized, relevant demographic variables in Group 1 (Community knowledge prior to radio broadcasts; $\mathrm{n}=124$ ), Group 2 (Screening behavior prior to radio broadcasts; $n=243$ ) and
Group 3 (Knowledge and behavior following radio broadcasts; $n=233$ ) were compared to assess for important differences that could affect the validity of the results (Table 1). Women in Groups 1, 2, and 3 were similar on the majority of demographic variables. Women in Group 1 were more likely to be married and had fewer lifetime sex partners than women in Group 3. However, over $90 \%$ of women in both groups reported two or fewer lifetime partners. Women in Group 1 had received more Pap smears in their lifetimes, and they were more likely to have been screened within the past year than women in Group 3. There was a significant relationship between age and the total lifetime number of Pap smears obtained (correlation 14\%, $P=0.0017)$ which did not differ between groups.

Comparison of knowledge before and after the radio broadcasts. To compare knowledge before and after the radio broadcasts, the percentage of correct responses in Group 3 (Knowledge and behavior following radio broadcasts; $n=233$ ) was compared to that in (Group 1: Community knowledge prior to radio broadcasts; $\mathrm{n}=$ 124). Women surveyed after the radio broadcasts (Group 3) knew more than women surveyed before the radio broadcasts (Group 1) on all questions related to cervical cancer and Pap smears (Table 2). The women interviewed following the radio broadcast were more familiar with the term "cervical cancer" (91\% versus $78 \%, P=$ 0.0004 ), were better able to identify gynecological exams or Pap smears as a method of cervical cancer prevention (79\% versus $69 \%, P=0.001$ ), and were more apt to state that the primary purpose of the Pap smear was cancer detection (61\% versus $46 \%, P<0.0001)$.

Recruitment of high-risk women for screening using the radio program. To determine whether radio programs could successfully recruit high-risk women for cervical cancer screening, we compared the numbers of highrisk women who attended organized 
TABLE 1. Comparison of demographic variables among subjects assessed before and after radio broadcasts about cervical cancer and screening, Honduras, 2003

\begin{tabular}{|c|c|c|c|c|c|}
\hline & $\begin{array}{l}\text { Group 1: Community } \\
\text { knowledge prior } \\
\text { to radio broadcasts } \\
\qquad(n=124)\end{array}$ & $\begin{array}{l}\text { Group 2: Screening } \\
\text { behavior prior } \\
\text { to radio broadcasts } \\
\qquad(n=243)\end{array}$ & $\begin{array}{l}\text { Group 3: Knowledge } \\
\text { and behavior following } \\
\text { radio broadcasts }{ }^{\mathrm{a}} \\
(n=233)\end{array}$ & $\begin{array}{c}\text { Group } 1 \\
\text { compared with } \\
\text { Group 3; } \\
P \text { value }\end{array}$ & $\begin{array}{c}\text { Group } 2 \\
\text { compared with } \\
\text { Group 3; } \\
P \text { value }^{\mathrm{b}}\end{array}$ \\
\hline Mean age $\pm S D^{c}$ (range) & $38.0 \pm 13.1(17-77)$ & $36.9 \pm 13.2(15-88)$ & $38.6 \pm 12.0(17-75)$ & $N S^{d}$ & NS \\
\hline Mean age at first birth \pm SD (range) & $19.1 \pm 3.1(14-30)$ & $\ldots^{e}$ & $19.8 \pm 3.7(13-33)$ & NS & $N A^{\dagger}$ \\
\hline Mean age at first coitus \pm SD (range) & $18.0 \pm 3.2(9-30)$ & $\ldots$ & $18.6 \pm 3.6(9-34)$ & NS & NA \\
\hline Mean number sex partners $\pm S D$ (range) & $1.2 \pm 0.5(1-3)$ & $1.6 \pm 1.1(1-10)$ & $1.5 \pm 0.8(1-6)$ & 0.0001 & NS \\
\hline Number using family planning, $(\%)^{g}$ & $70(59 \%)$ & $138(67 \%)$ & $131(69 \%)$ & NS & NS \\
\hline \multicolumn{6}{|l|}{ Marital status ${ }^{9}$} \\
\hline Number married (\%) & $41(39 \%)$ & $78(32 \%)$ & $57(25 \%)$ & & \\
\hline Number living with partner (\%) & $49(47 \%)$ & $115(48 \%)$ & $124(55 \%)$ & & \\
\hline Number single (\%) & $15(14 \%)$ & $49(20 \%)$ & $46(20 \%)$ & 0.03 & NS \\
\hline Number with $>5$ lifetime Pap smears $(\%)^{g}$ & $52(48 \%)$ & $\ldots$ & $71(31 \%)$ & 0.003 & NA \\
\hline
\end{tabular}

TABLE 2. Cancer screening knowledge prior to and following radio broadcasts, Honduras, 2003

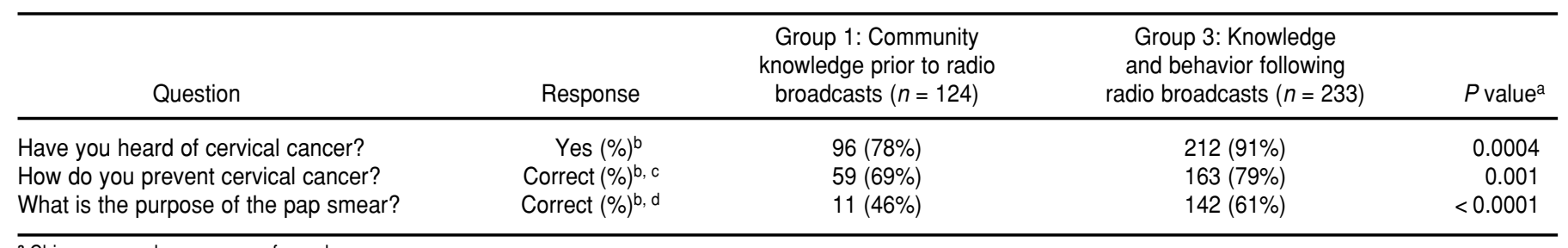

a Chi-square analyses were performed.

${ }^{b}$ Percentages are based on the number of complete responses. Cell totals may be less than the total number in the group.

c Correct answers included "Gynecological exams" and "Pap smears."

"Correct answers included "Detection of cancer."

screening activities before and after the radio broadcasts (comparison of Groups 2 and 3). The proportion of women aged 30 and over who attended the organized screening activities increased from $64 \%$ prior to the radio broadcasts to $74 \%$ afterward $(P=$ $0.02)$. The proportion of women who had not been screened in two years or more increased from $30 \%$ to $65 \%$ ( $P<$ 0.0001) (Table 3).
Training of community nurses

To train community nurses in the importance of Pap smear screening and the proper triage of results, a 45minute lecture presentation was given during their monthly educational meeting. This lecture had a significant impact on knowledge: recognition of cervical cancer as a leading cause of cancer mortality in Honduran women rose from $28 \%$ to $100 \%(P<0.0001)$, understanding the importance of the Pap smear in detecting cervical dysplasia improved from $3 \%$ to $47 \%$ ( $P<$ 0.0001 ), understanding the correct management of cervical intraepithelial neoplasia (CIN) improved from $41 \%$ to $91 \%(P<0.0001)$, and recognition of the age-associated risk of dysplasia improved from $0 \%$ to $72 \%(P<0.0001)$ (Table 4). 
TABLE 3. Cancer screening behavior prior to and following radio broadcasts, Honduras, 2003

\begin{tabular}{|c|c|c|c|}
\hline Characteristics & $\begin{array}{l}\text { Group 2: Screening behavior } \\
\text { prior to radio broadcasts } \\
\qquad(n=243)\end{array}$ & $\begin{array}{c}\text { Group 3: Knowledge and } \\
\text { behavior following radio } \\
\text { broadcasts }(n=233)\end{array}$ & $P$ value $^{\mathrm{a}}$ \\
\hline Number of women age 30 and over $(\%)^{b}$ & $154(64 \%)$ & $170(74 \%)$ & 0.02 \\
\hline Number of women with no Pap test in 2 or more years $(\%)^{b}$ & $72(30 \%)$ & $151(65 \%)$ & $<0.0001$ \\
\hline
\end{tabular}

a Chi-square analyses were performed.

${ }^{b}$ Percentages are based on the number of complete responses. Cell totals may be less than the total number in the group.

TABLE 4. Change in nurses' knowledge about cervical cancer and screening following training, Honduras, 2003 and 2005

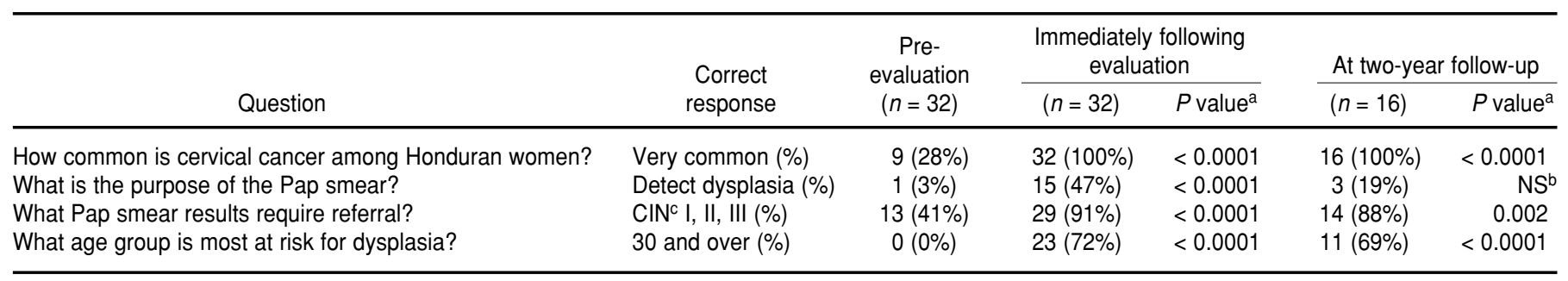

${ }^{a}$ Compared with pre-evaluation scores. All responses were obtained anonymously to protect nurse confidentiality, therefore two-sample comparisons using Fisher exact tests were used instead of paired analyses.

${ }^{\circ} \mathrm{NS}=$ not significant at $P<0.05$ level.

${ }^{c} \mathrm{CIN}=$ cervical intraepithelial neoplasia.

Those nurses who had heard the original presentation and were still working in the communities $(\mathrm{n}=16)$ were surveyed again two years later. Comparisons were made to the nurses' initial pre-test evaluation. All nurses recalled that cervical cancer was very common among Honduran women $(P<0.0001), 88 \%$ recalled the correct management of CIN $(P=$ $0.002)$, and $69 \%$ recalled the agerelated risk of dysplasia $(P<0.0001)$. Only 19\% recalled that the Pap smear detects pre-invasive lesions (not significant) (Table 4).

\section{DISCUSSION}

Prior to the educational program, both patients and health care providers in Honduras had limited knowledge about the importance of Pap smear screening in preventing cervical cancer and about the age-related risk of dysplasia. An inexpensive program using radio broadcasts and short lecture presentations to nurses had a substantial impact. Not only did knowledge improve following both interventions, but the nurses recalled important points about cervical cancer screening two years later. In addition, the radio broadcasts successfully recruited high-risk women for screening.

This study demonstrates that successful education programs are possible in developing nations when working within the constraints of existing community resources. To create an inexpensive, sustainable program, community volunteers were involved in all aspects of the project. Recruitment of volunteers was easy-the health center and radio station staffs readily donated their time and resources to the project. Their willingness to help may be due to a strong sense of community loyalty. Most people who work in these communities have lived there for many years, and are thus motivated to participate in a project that they perceive as directly benefiting their neighbors, their families, and themselves. The health care providers' belief in the importance of this project may be one reason why they recalled important points about cervical cancer screening two years later.

Other studies in Latin America and with Latino populations in the United States and Canada have emphasized the importance of involving the community in cervical cancer education and screening efforts $(6,16)$. The Alliance for Cervical Cancer Prevention recently published a summary of lessons learned from a variety of international projects. Their recommendations for effective community-based cervical cancer prevention programs in developing countries were to: (a) include key stakeholders in the community and community health workers in program development and implementation, (b) involve local health care workers in the design of educational materials, and (c) provide training for health care workers (16). This project provides an example of the successful implementation of these principles.

Another important consideration for sustainability is the women's commitment to continued screening after their first Pap tests. The high number of lifetime Pap smears per woman in 
the community assessment (Group 1) and the high number of women with a prior screening history who presented for repeat Pap smears at organized screening days (Groups 2 and 3) seem to indicate that once a woman has begun screening, she makes efforts to continue screening. This has implications for sustainability because an intensive, one-time effort to recruit previously unscreened women might have a sustained impact as these women become part of the culture of screening. Results from this study as well as the world literature indicate that media may be effective to recruit women for health services. Use of the media appears to be a cost-effective means of affecting health behavior (17), and has been successfully employed in developing countries to increase attendance at cervical cancer screening activities (18).

This study has a number of limitations because it was not a randomized experimental design. When evaluating the impact of the radio program, cross-sectional comparisons were performed between women who may not be entirely equivalent. Different women were included in Group 1 (Community knowledge prior to radio broadcasts; $\mathrm{n}=124$ ), Group 2 (Screening behavior prior to radio broadcasts; $n=243$ ), and Group 3 (Knowledge and behavior following radio broadcasts; $n=233$ ). Although the groups were similar on many demographic variables, the higher rate of marriage and the increased level of screening in Group 1 may indicate that this group of women was of a higher socioeconomic status than women in Group 3. In Honduras, only couples with means can afford to legally marry, and only women with disposable income can participate in regular screening in private clinics. The women attending the project's outreach services, in contrast, were all availing themselves of free screening (Groups 2 and 3). Based on existing studies, however, one would expect that women of higher socioeconomic status and those who participate in screening regularly would know more about cervical cancer than those of lower socioeconomic status or those who have been screened less often (19, 20). The opposite was found in this study, which supports the hypothesis that the radio program improved knowledge in the community.

Limitations also exist with regards to the nurses' training program. We do not know if the nurses received any additional training in cervical cancer prevention during the two-year period between the provider training intervention and the final evaluation. Because the nurses do exert control over the content of their educational programs, however, seeking additional training on cervical cancer prevention would be considered a successful outcome of the original training. Further research in this area could address the above limitations.

\section{CONCLUSIONS}

In countries without organized cervical cancer screening, patient education is crucial to increase the number of women screened. This study demonstrates that inexpensive educational programs utilizing existing community resources can successfully improve cervical cancer knowledge and screening behavior. This model could be adopted on a larger scale to increase cervical cancer awareness and screening in developing countries.

Acknowledgments. Funding for the community education project was provided by the Association for Cervical Cancer Prevention Small Grants Program. The Alliance for Cervical Cancer Prevention, funded by the Bill \& Melinda Gates Foundation, is a consortium of five agencies that work with developing country partners to clarify, promote, and implement strategies for preventing cervical cancer. Funding for the development of the manuscript was provided by the Building Interdisciplinary Research Careers in Women's Health (BIRCWH) Scholar program, an institutional K-12 award from the U.S. National Institutes of Health. The authors would like to thank the staff of the Emma Romero de Callejas Centro de Cancer (Tegucigalpa, Honduras) and Pablo Maldonado of Radio Yuscaran (Yuscaran, Honduras) for their contributions to this project.

\section{REFERENCES}

1. Denny L. The prevention of cervical cancer in developing countries. BJOG 2005;112(9): 1204-12.

2. Watkins MM, Gabali C, Winkleby M, Gaona E, Lebaron S. Barriers to cervical cancer screening in rural Mexico. Int J Gynecol Cancer 2002;12(5):475-9.

3. Gichangi P, Estambale B, Bwayo J, et al. Knowledge and practice about cervical cancer and Pap smear testing among patients at Kenyatta National Hospital, Nairobi, Kenya. Int J Gynecol Cancer 2003;13(6):827-33.

4. Rezaei MB, Seydi S, Alizadeh SM. Effects of 2 educational methods on the knowledge, attitude, and practice of women high school teachers in prevention of cervical cancer. Cancer Nurs 2004;27(5):364-9.

5. Claeys P, Gonzalez C, Gonzalez M, Page H, Bello RE, Temmerman M. Determinants of cervical cancer screening in a poor area: results of a population-based survey in Rivas, Nicaragua. Trop Med Int Health 2002;7(11): 935-41.

6. Austin LT, Ahmad F, McNally MJ, Stewart DE. Breast and cervical cancer screening in Hispanic women: a literature review using the health belief model. Womens Health Issues 2002;12(3):122-8.

7. Nguyen TT, McPhee SJ, Nguyen T, Lam T, Mock J. Predictors of cervical Pap smear screening awareness, intention, and receipt among Vietnamese-American women. Am J Prev Med 2002;23(3):207-14.

8. Lee MC. Knowledge, barriers, and motivators related to cervical cancer screening among Korean-American women. A focus group approach. Cancer Nurs 2000;23(3):168-75.

9. Agurto I, Bishop A, Sanchez G, Betancourt Z, Robles S. Perceived barriers and benefits to cervical cancer screening in Latin America. Prev Med 2004;39(1):91-8.

10. Dabash R, Vajpayee J, Jacob M, et al. A strategic assessment of cervical cancer prevention and treatment services in 3 districts of Uttar Pradesh, India. Reprod Health 2005;2:11. 
11. Tarwireyi F, Chirenje ZM, Rusakaniko S. Cancer of the cervix: knowledge, beliefs and screening behaviours of health workers in Mudzi District in Mashonaland East Province, Zimbabwe. Cent Afr J Med 2003;49(7-8):83-6.

12. Bishop A, Sherris J, Tsu VD, Kilbourne-Brook M. Cervical dysplasia treatment: key issues for developing countries. Bull Pan Am Health Organ 1996;30(4):378-86.

13. Arrossi S, Sankaranarayanan R, Parkin DM. Incidence and mortality of cervical cancer in Latin America. Salud Publica Mex 2003;45 Suppl 3:S306-14.

14. United States Department of Health and Human Services, Centers for Disease Control and Prevention. United States cancer statistics: 1999-2002 incidence and mortality. [Webbased report.] 2005. (Accessed 5 June 2007, at http://www.healthypeople.gov/document/ HTML/Volume1/03Cancer.htm.

15. Honduras, Secretaría del Estado del Despacho Presidencial. Informe presidencial. Anexo 4. Información por departamento y municipio. Tegucigalpa: Secretaría de Estado del Despacho Presidencial, 2004. 37 pages.

16. Agurto I, Arrossi S, White S, et al. Involving the community in cervical cancer prevention programs. Int J Gynaecol Obstet 2005;89 Suppl 2:S38-45.

17. Hogan DR, Baltussen R, Hayashi C, Lauer JA, Salomon JA. Cost effectiveness analysis of strategies to combat HIV/AIDS in developing countries. BMJ 2005;331(7530):1431-7.

18. Risi L, Bindman JP, Campbell OM, et al. Media interventions to increase cervical screening uptake in South Africa: an evalua- tion study of effectiveness. Health Educ Res 2004;19(4):457-68.

19. Wellensiek N, Moodley M, Moodley J, Nkwanyana N. Knowledge of cervical cancer screening and use of cervical screening facilities among women from various socioeconomic backgrounds in Durban, Kwazulu Natal, South Africa. Int J Gynecol Cancer 2002;12(4):376-82.

20. McFarland DM. Cervical cancer and Pap smear screening in Botswana: knowledge and perceptions. Int Nurs Rev 2003;50(3):167-75.

Manuscript received 8 July 2006. Revised version accepted for publication 10 September 2007.
RESUMEN

\section{Programa educacional basado en la comunidad mejora el conocimiento sobre el cáncer cervicouterino y la conducta ante el tamizaje de mujeres en Honduras}

Palabras clave
Objetivos. Examinar los cambios ocurridos en el conocimiento sobre el cáncer cervicouterino y el comportamiento ante el tamizaje después de un programa educacional basado en la comunidad en Honduras.

Métodos. El programa consistió en transmisiones radiales dirigidas a mujeres de zonas rurales y conferencias a enfermeros de la comunidad. La eficacia de las transmisiones radiales se evaluó mediante un diseño transversal (grupos de control: $n=$ 124 y $n=243$; grupo de intervención: $n=233$ ). Se utilizó una prueba previa y otra posterior para evaluar el programa de entrenamiento de enfermeros $(n=32)$. Después de dos años se repitió la prueba a un subgrupo de enfermeros $(n=16)$. Se emplearon las pruebas exacta de Fisher, de la $t$ de Student y de la ji al cuadrado.

Resultados. Las transmisiones radiales elevaron la proporción de mujeres familiarizadas con el término "cáncer cervicouterino", que podían identificar las vías para prevenir el cáncer cervicouterino y que comprendían los objetivos de la prueba de Papanicolau. Además, mediante el radio se reclutaron exitosamente para tamizar más mujeres de los grupos de mayor edad y menos tamizadas. Con el programa para enfermeros se mejoró la comprensión del uso correcto de la prueba de Papanicolau, del riego relativo de displasia según la edad y de la conducta apropiada a seguir ante resultados alterados. Los enfermeros retenían una cantidad importante de conocimientos dos años después del entrenamiento.

Conclusiones. En los países en desarrollo, el empleo de programas educacionales poco costosos basados en la comunidad mediante transmisiones radiales y conferencias puede elevar el conocimiento sobre el cáncer cervicouterino y mejorar el comportamiento ante el tamizaje.

Medios de comunicación, países en desarrollo, mujeres, educación en salud, tamizaje masivo, neoplasias del cuello uterino, displasia del cuello uterino, Honduras. 